\title{
PENYULUHAN TENTANG MENUMBUHKAN JIWA KEWIRAUSAHAAN ISLAMI BAGI PEMUDA DI KELURAHAN MONJOK BARAT KECAMATAN SELAPARANG KOTA MATARAM
}

\author{
M. Firmansyah \\ Fakultas Ekonomi dan Bisnis Universitas Mataram \\ firmansyah.feb@unram.ac.id. \\ Sahri \\ Fakultas Ekonomi dan Bisnis Universitas Mataram \\ sahri.feb@unram.ac.id \\ Abdul Manan \\ Fakultas Ekonomi dan Bisnis Universitas Mataram \\ abdmananfeb@gmail.com \\ Iwan Harsono \\ Fakultas Ekonomi dan Bisnis Universitas Mataram \\ iwanharsono@yahoo.com \\ Muhammad Irwan \\ Fakultas Ekonomi dan Bisnis Universitas Mataram \\ dae.wan65@yahoo.com
}

\section{Article History:}

Received: 31 Mei 2021

Revised: 5 Juni 2021

Accepted: 5 Juni 2021

DOI:

10.29303/abdimassangkabi ra.v1i2.37
Abstrak: Tujuan dari kegiatan pengabdian kepada masyarakat ini adalah memberikan pemahaman tentang (a) Arti dan prinsip-prinsip kewirausahaan syariah; (b) Merintis Kewirusahaan Islami; (c) Etika Bisnis Islami; (d) Karakteristik Wirausahawan Islami dan (e) Unsur-Unsur Wirausaha Islami.Untuk mencapai tujuan tersebut, solusi yang dilakukan adalah : memberikan pemahaman tentang (a) Arti dan prinsip-prinsip kewirausahaan syariah; (b) Merintis Kewirusahaan Islami; (c) Etika Bisnis Islami; (d) Karakteristik Wirausahawan Islami dan (e) Unsur-Unsur Wirausaha Islami.

Kegiatan ini dapat dikatakan berjalan baik dan berhasil dilihat dari beberapa indikator yaitu: (a) Kehadiran peserta yang hadir melebihi setengah yang telah ditetapkan yang dihadiri oleh peserta baik laki - laki dan perempuan, (b) Diskusi dan tanya jawab yang memberikan gambaran tentang permasalahan yang dihadapi peserta terutama berkenaan langkah-langkah memulai atau merintis 


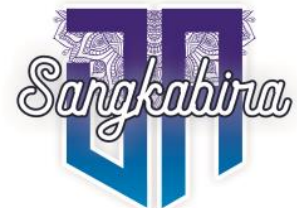

Vol. 1, No. 2, Juni 2021

usaha, (c) Peserta bersedia untuk menjalankan usaha dengan memperhatikan ketersedian modal usaha dalam arti luas.

Saran yang berkenaan dengan kegiatan ini adalah (a) Tim harus menindaklanjuti keinginan peserta untuk memberikan penyuluhan berkenaan dengan pemantapan pemahaman mengenai berwirausaha secara Islami maupun pemanfaatan modal usaha dengan prinsp-prinsip syariah; (b) Penyajian tim masih dalam bentuk ceramah, dikembangkan dalam bentuk pendidikan seperti mempraktekkan langkahlangkah memulai usaha dengan prinsip-prinsip Islami.

Kata Kunci: Pemuda, Kewirausahaan Islami, Etika Bisnis Islami

\section{Pendahuluan}

Kemajuan pembangunan suatu bangsa pada masa mendatang tergantung pada kualitas sumber daya manusianya salah satunya adalah pemuda. Pemuda masa depan adalah pemuda yang mampu bersaing, berkualitas, kokoh dan sanggup menghadapi persaingan global terutama berkenaan dengan informasi dan teknologi. Pemuda yang diharapkan adalah pemuda yang mampu beraktivitas secara mandiri tanpa sepenuhnya bergantung dan berharap adanya bantuan dari pihak lain. Pemuda masa depan adalah pemuda yang berdiri di atas kaki sendiri (mandiri) dan mampu menciptakan lapangan kerja untuk orang lain. Pemuda yang memiliki karakteristik wirausahawan yang diharapkan akan mampu menjalani roda perekonomian yang semakin ketat dan penuh persaingan.

Perjalanan ekonomi global yang masih didominasi oleh sistem ekonomi liberal kapitalis dengan cirinya antara lain bersifat individual dan maksimasi profit dengan materialisme menjadi tujuan utamanya. Dampaknya adalah orang berlomba-lomba untuk mengejar materi tanpa memperhatikan asal dan cara memperolehnya dan melanggar etika. Sisi lain, nilai-nilai spritual diabaikan bahkan dilanggar demi meraih materi. Orientasi materialisme telah menyebabkan lunturnya jiwa kebersamaan, tolong menolong karena setiap individu lebih mementingkan kepentingan dirinya. Banyak dampak negatif yang dirasakan oleh setiap pelaku ekonomi terutama konsumen baik dalan jangka panjang maupun dalam jangka pendek.

Ekonomi Islam hadir dengan membawa nilai-nilai yang dianut oleh setiap pelaku ekonomi dalam menjalankan aktivitasnya. Salah satu aktivitas yang mengedepankan nilai-nilai adalah berwirausaha. Islam memberikan penekanan kepada setiap pelaku usaha termasuk yang berwirausaha untuk memiliki karakter wirausaha berdasarkan syariah Islam. Oleh karenanya wirausahawan muslim yang berkarakter menjadi 
sebuah pengharapan dalam perjalanan ekonomi konvensional sekarang ini. Pelaku usaha khususnya yang berusaha secara mandiri (wirausaha) harus memiliki etika islami dalam menjalankan usahanya, agar hasil yang diperoleh dari usaha tersebut mengandung keberkahan. Salahsatu pelaku wirausaha yang diharapkan memiliki hal tersebut adalah pemuda, karena merekalah yang memiliki jumlah yang lebih besar dari pelaku ekonomi lainnya.

Kelurahan Monjok Barat merupakan kelurahan yang letaknya strategis dan terbuka peluang pemuda untuk menjadi seorang wirausahawan. Kehadiran pemuda yang berwirausaha menjadi faktor pendorong terjadinya peningkatan aktivitas ekonomi di daerah tersebut. Pemuda yang berwirausaha akan memberi pengaruh terhadap kesempatan kerja, peningkatan pendapatan sekaligus mengurangi penduduk dari kemiskinan. Namun demikian, pemahaman para pemuda terhadap selukbeluk berwirausaha mulai dari konsep dan karakteristik termasuk berwirausaha secara islami masih relatif kurang. Aktivitas usaha masih dilakukan berdasarkan pengalaman tanpa didukung oleh pemahaman dan ilmu yang memadai. Terdapatnya lokasi-lokasi terbuka untuk melakukan usaha adalah salah satu faktor yang mendorong pemuda untuk melakukan usaha di samping adanya faktor-faktor lain.

Penduduk yang berada di Kelurahan Monjok Barat melakukan aktivitas usaha termasuk yang dilakukan oleh pemuda baik secara mandiri maupun bekerja pada orang lain. Sebahagian besar dari mereka adalah pemuda dan di antaranya ada yang muslim. Dalam menjalankan usahanya setiap pelaku bisnis harus memiliki nilai-nilai keimanan dan ketakwaan serta beretika. Dengan adanya ketakwaan, seorang pebisnis tidak perlu menghindari persaingan selama dilakukan secara santun dan penuh keakraban; dalam arti persaingan itu tidak dalam konteks saling menjatuhkan (Baidan, dkk, 2008). Sedangkan Etika bisnis adalah penerapan etika secara umum terhadap prilaku bisnis (Hamali, dkk, 2017). Dengan memiliki prinsip ketakwaan dan etika berwirausaha akan berdampak pada jenis dan pemasaran produk yang dirasa masih mengalami kendala.

Berkenaan dengan permasalahan tersebut, maka pemuda sangat perlu untuk diberikan ilmu pengetahuan berkenaan dengan kewirausahaan khususnya kewirausahaan Islami. Ilmu pengetahuan dapat diberikan melalui bentuk penyuluhan, agar pelaku para pemuda dapat mengetahui secara lengkap tentang konsep, karakteristik, keunggulan dan etika berwirausaha. Dengan adanya informasi ini akan membantu para pemuda untuk menjadi seorang wirausahawan muslim sebagai faktor penentu maju dan mundurnya usaha yang dilakukan. Tim pengabdian Fakultas Ekonomi dan Bisnis Universitas Mataram terdorong untuk melaksanakan kegiatan pengabdian dalam bentuk penyuluhan, yang tertuju pada pemuda untuk memahami tentang konsep, karakteristik kewiruasahaan 


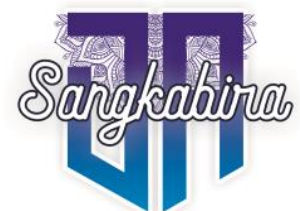

Vol. 1, No. 2, Juni 2021

islami, sebagai modal dasar dalam melakukan dan menjalan usaha secara wirausaha.

Permasalahan yang dihadapi oleh masayarakat/pemuda adalah pemahaman terhadap konsep, karakteristik kewirausahaan islami masih relatif kurang, sehingga berdampak pada proses usaha yang telah dijalankan, dan keterbatasan informasi yang berkenaan kewirausahaan baik secara konvensional maupun secara islami.

\section{Metode pelaksanaan}

Permasalahan yang dihadapi oleh mitra dapat dipecahkan dengan melakukan kegiatan Pengabdian Kepada Masyarakat dalam bentuk kemitraan. Kegiatan yang dilakukan adalah memberikan penyuluhan dan pengetahuan tentang konsep, karakteristik, prinsip-prinsi berwirusaha secara Islami. Pelaksanaan kegiatan dilakukan melalui beberapa tahap yaitu :

\section{Tahap Persiapan}

Tahap persiapan meliputi kegiatan yang berkenaan dengan pelaksanaan yang akan dilakukan oleh tim pengabdian kepada masyarakat mulai dari perencanaan, penentuan waktu pelaksanaan, jumlah peserta hingga pelaksanaan penyuluhan. Langkah awal yang dilakukan adalah menghubungi Lurah, kepala lingkungan dan tokoh pemuda, untuk melakukan identifikasi peserta yang relevan dengan kegiatan ini.

\section{Tahap Pelaksanaan}

Tahap pelaksanaan merupakan waktu diadakannya kegiatan penyuluhan yang telah ditentukan didasarkan pada kesepakatan dengan kepala lingkungan dan tokoh pemuda baik berkenaan dengan waktu maupun tempat pelaksanaan. Dalam tahap ini dilakukan tatap muka dengan peserta yang diawali dengan memberikan materi-materi dengan metode ceramah yang berkaitan dengan kewirausahaan islami.

\section{Hasil dan pembahasan}

Pelaksanaan kegiatan penyuluhan dilaksanakan pada tanggal 22 Oktober 2020 yang dimulai jam 20.00 (ba'da Isya) hingga selesai. Tempat melakukan kegiatan adalah rumah salah satu tokoh masyarakat sekaligus Ketua RT 1 di Kelurahan Monjok Barat. Kegiatan penyuluhan dihadiri oleh sekitar 16 orang peserta yang terdiri dari pemuda-pemuda yang berjenis kelamin laki-laki maupun perempuan dan tokoh masyarakat setempat. Latar belakang peserta adalah pemuda yang telah memiliki usaha, dan juga mahasiswa yang kuliah dan sambil bekerja serta mahasiswa yang hanya berkonsentrasi untuk kuliah. Bagi pemuda yang telah memiliki usaha, mereka berusaha menjual minuman ringan, makanan dan usaha fotocopy, jual pulsa dan percetakan. 
Kegiatan penyuluhan dimulai dengan melakukan perkenalan antara tim pengabdian kepada masyarakat berkenaan dengan tujuan dan maksud diadakan kegiatan penyuluhan ini. Selanjutnya tim pengabdian secara bergiliran menjelaskan dan menguraikan hal-hal yang berkenaan dengan kewirausahaan baik secara konvensional maupun berdasarkan syariah Islam. Penyampain materi dilakukan secara umum dan disertai dengan contoh-contoh kasus faktual tentang jatuh bangunnya pengusahapengusaha sukses baik berskala daerah, nasional maupun internasional.

Setelah tim menyampaikan materi lebih kurang 60 menit, kegiatan dilanjutkan dengan diskusi, dengan memberi kesempatan kepada peserta untuk bertanya dan menceritakan pengalaman tatkala sedang menjalani usaha serta langkah-langkah yang dilalukan jika ingin memulai usaha. Beberapa pertanyaan yang diajukan oleh peserta berkenaan dengan permasalahan yang dihadapi adalah :

1. Pertanyaan dari seorang peserta yang berstatus Mahasiswa. Ia menceritakan tentang keinginannya untuk kuliah sambil berusaha tetapi ada sika ragu-ragu untuk memulai karena adanya permasalahan yang tengah dihadapi bersama yaitu covid-19. Ia mengharapkan bagaimana untuk menghilangkan keraguan tersebut dan mampu meyakinkan diri untuk memulai usaha.

Menanggapi pertanyaan ini, secara bergantian tim memberikan pandangan bahwa hal itu merupakan hal yang wajar bagi seseorang yang memulai usaha, terlebih pada masa sekarang. Tim memberikan contoh tentang keberhasilan pengusaha nasional yang jatuh bangun memulai usaha tidak hanya mencoba pada satu jenis bahkan banyak jenis usaha yang dicoba hingga menemukan usaha yang sudah berkembang pesat sekarang ini.

Tim juga menambahkan bahwa sikap ragu-ragu dalam memulai suatu usaha apa saja sebaiknya dihilangkan karena akan menyebabkan sesuatu yang direncanakan tidak akan berjalan dengan baik. Untuk memulai usaha harus dimulai dengan niat yang kokoh, jauhkan pandangan rugi dan gagal serta mantapkan jiwa berusaha dengan bertawakkal kepada yang Maha Kuasa. Sikap yang penuh dengan optimis dan tawakkal akan mampu menghapus keraguan yang tengah dihadapi sekarang.

2. Peserta lain yang berusaha dalam penjualan makanan dan minuman sementara ini juga bekerja pada usaha orang lain. Dia bercita-cita ingin berhenti bekerja dan ingin mengembangkan usaha yang dilakukan secara mandiri. Kendala yang dihadapi sekarang adalah keterbatasan modal usaha serta sepinya pembeli.

Menanggapi hal yang demikian, tim memberikan pemahaman bahwa jika dalam diri ada kemauan untuk berusaha mandiri itu lebih baik. Dengan berusaha mandiri seseorang dapat menata dan mengelola usahanya sesuai dengan keinginan dan tujuan yang akan dicapai. Dengan 


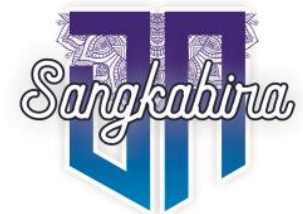

Vol. 1, No. 2, Juni 2021

berusaha secara mandiri seseorang akan bebas melakukan ekspresi, menemukan kreasi dan inovasi baru tanpa ada pihak lain yang mencegahnya.

Berkenaan dengan modal usaha tim telah menguraikan bahwa modal usaha dapat bersumber dari milik sendiri dan pihak luar. Jika berhubungang dengan pihak luar, maka banyak tersedia lembagalembaga keuangan bank maupun non bank yang menjalankan usaha secara konvensional dan syariah. Bila ntuk menghindari dari praktek bunga dalam peminjaman modal usaha dapat berhungungan dengan lembaga keuangan syariah baik bank dan non bank yang menerapkan sistem bagi hasil.
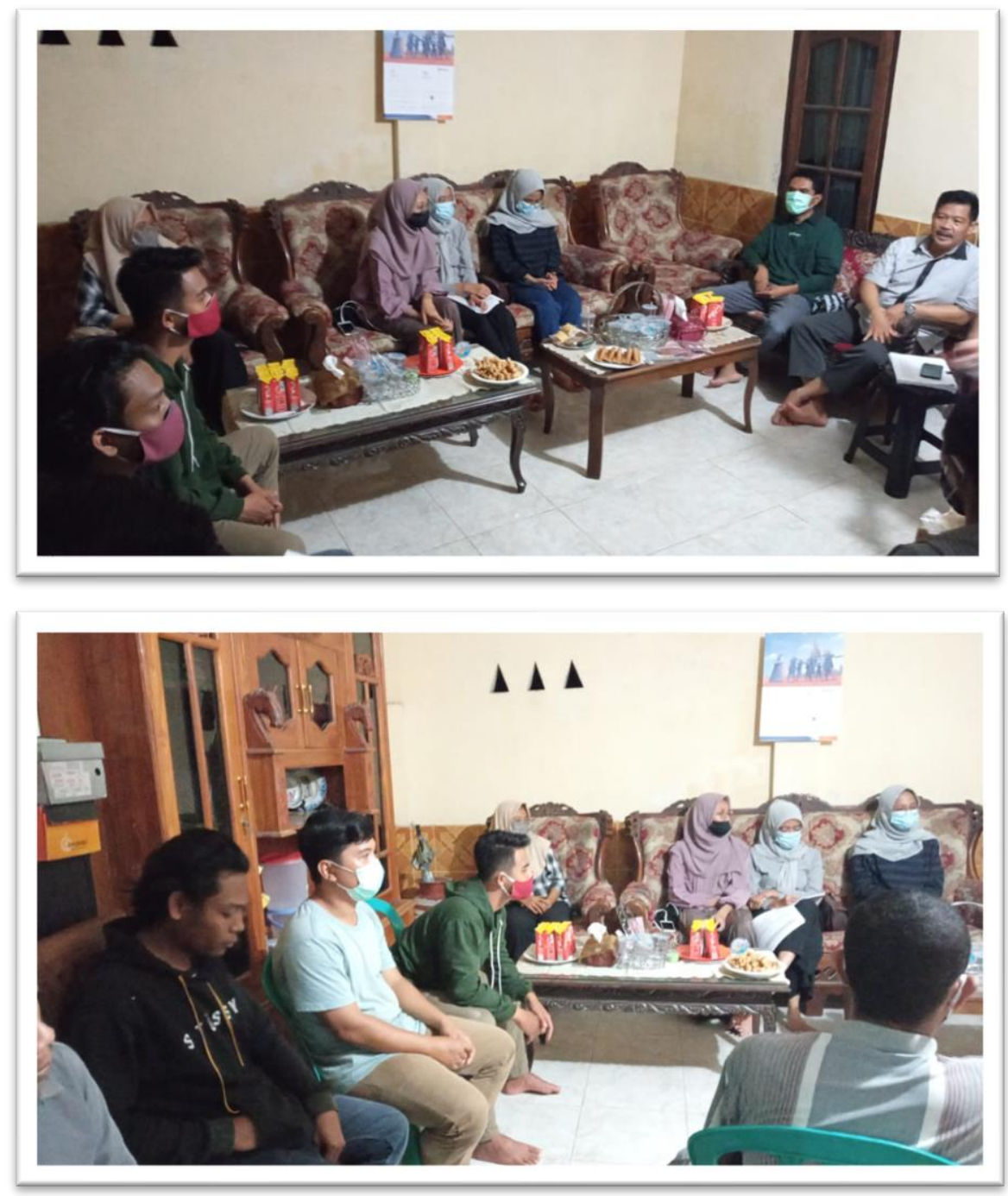

Materi yang disampaikan oleh tim pengabdian telah mampu memberikan tambahan pengetahuan kepada peserta sehingga dapat dijadikan informasi yang dapat dipergunakan jika akan memulai dan 
melanjutkan usaha. Berdasarkan hasil diskusi dan tanya jawab yang telah dilakukan, dapat diketahui permasalahan yang dihadapi oleh peserta. Beberapa pertanyaan dari peserta dan merupakan permasalahan yang dihadapi peserta dapat dihimpun sebagai berikut :

1. Peserta memiliki pengetahuan yang terbatas berkenaan dengan arti makna dan prinsip-prinsip kewirausahaan baik secara konvensional maupun berdasarkan syariah Islam.

2. Sepinya pelanggan atau konsumen yang memanfaatkan usaha yang dijalani terutama pada masa pandemi covid-19 ini.

3. Ada keinginan dari peserta untuk melakukan usaha secara mandiri dan berhenti dari tempat bekerjanya sekarang, namun ditunda dulu untuk menghimpun modal yang bersumber dari usaha sendiri yang dirasa belum cukup terpenuhi.

4. Usaha yang dijalani sekarang masih bersifat informal karena berbagai keterbatasan yang dihadapi baik berkenaan dengan tempat usaha, ijin usaha, masih dikelola sendiri dan belum punya kemampuan untuk memperkerjakan tenaga kerja.

Berdasarkan pertanyaan dan identifikasi permasalahan tersebut, tim pengabdian telah memberikan penjelasan dan uraian secara umum berkenaan dengan permasalahan yang tengah dihadapi. Tim juga memberikan pandangan tentang prinsip meraih keungan maksimal secara islami yang diperbolehkan sepanjang tidak mendholimi pihak (konsumen) yang membutuhkan barang tersebut. Tim juga memberikan pengetahuan tentang hal-hal yang harus diperhatikan dalam berusaha seperti jujur, tidak berbohong, tidak melakukan kecurangan serta harus dapat dipercaya dan mampu melaksanakan amanah yang diberikan pihak lain kepada dirinya.

\section{Kesimpulan dan saran}

\section{A. Simpulan}

Berdasarkan hasil pelaksanaan pengabdian pada masyarakat dan pembahasan di atas dapat ditarik beberapa simpulan sebagai berikut :

1. Peserta ingin memulai usaha dengan berupaya menghimpun modal sendiri dan pada saatnya akan meninggalkan pekerjaannya sekarang. Peserta membutuhkan modal usaha lain ketika usaha yang dijalani sekarang mengalami penurunan jumlah pembeli atau pelanggan.

2. Peserta penyuluhan telah memiliki pengetahuan tambahan berkenaan dengan berwirausaha secara islami. Berdasarkan pengetahuan tersebut dapat diterapkan pada usaha yang dijalani sekarang.

\section{B. Saran -saran}

Berdasarkan hasik kegiatan ini dapat diberikan saran - saran konstruktif sebagai berikut 
Vol. 1, No. 2, Juni 2021

1. Tim harus menindaklanjuti keinginan peserta untuk memberikan penyuluhan berkenaan dengan pemantapan pemahaman mengenai berwirausaha secara Islami maupun pemanfaatan modal usaha dengan prinsi-prinsip syariah.

2. Penyajian tim masih dalam bentuk ceramah, dikembangkan dalam bentuk pendidikan seperti mempraktekkan langkah-langkah memulai usaha dengan prinsip-prinsip Islami.

\section{Daftar Pustaka}

Baidan, Nashrudin, dan Erwati Azis, 2008. Etika Islam Dalam Berbisnis. Zada Haniva, Solo.

Dawabah, Asyraf Muhammad. 2005. The Moslem Entrepreneur. Kiat Sukses Pengusaha Muslim. Lini Zikrul Media Intelektual, Jakarta.

Farid, 2017, Kewirausahaan Syariah, Kencana, Jakarta

Hamali, Arif Yusuf dan Eka Sari Budihastuti, , 2017, Pemahaman Kewirausahaan, Kencana, Jakarta.

Husain Syahatah, Sidiq Muh Al-Amin Adh Zdhahir, 2005, Transaksi Dan Etika Bisnis Islam, Visi Insani Publishing, Jakarta.

Idri, H. 2015. Hadis Ekonomi. Ekonomi Dalam Perspektif Hadis Nabi. Prenadmedia Group. Jakarta.

Muhammad. (tt). Etika Bisnis Islami. UPP. AMP YKPN. Yogyakarta.

Muslich. 2010. Etika Bisnis Islami. Ekonisia, Yogyakarta.

Suryana, 2016, Kewirausahaan Kiat dan Proses Menuju Sukses, Salemba Empat, Jakarta.

Suryana, Yuyus dan Kartib Bayu. 2010. Kewirausahaan. Pendekatan Karakteristik Wirausahawan Sukses. Edisi Kedua, Kencana, Prenadamedia Group. Jakarta.

Yusanto, Muhammad Ismail dan Muhammad Karebet Widjajakusuma. 2002. Menggagas Bisnis Islami. Gema Insani, Jakarta. 